
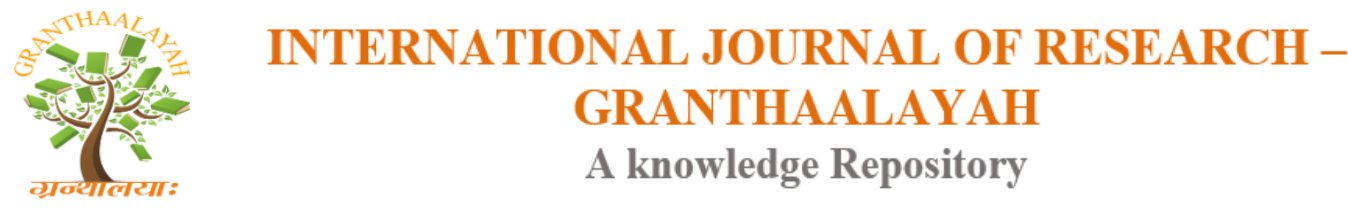

Management

\title{
PERCEPTION OF TAXPAYERS' TOWARDS E-FILE ADOPTION
}

\author{
Dr. Mohammad Anees ${ }^{1}$, Mr. Mukesh Kumar ${ }^{2}$ \\ ${ }^{1}$ Assistant professor, Department of Business Administration, University of Lucknow, India \\ ${ }^{2}$ Research Scholars, Department of Business Administration, University of Lucknow, India
}

\begin{abstract}
This paper try to build up an perceptive of the factors that influence citizens' adoption of electronic tax-filing services and to discuss taxpayer perception and satisfaction with an online system(e-filing system) for filing individual income tax returns. The data was collected through questionnaire and then was tabulized and analyzed with the help of respective tests using SPSS, MS Excel and other required methods have been used. A survey has been used to collect primary data and questionnaire approach was used in final analysis. Single cross sectional descriptive research design was used to determine taxpayers' perception. The result through questionnaires somehow discloses that most of the individuals facing problem regarding Lack of experience and knowledge in filing the return electronically and in the same questionnaires most of the individuals satisfy with the easiness and accuracy of e-filing. But when we go for overall experience of individuals regarding e-filing the still wants some improvement in the present efiling system. Questionnaires have been filled by different level of employees both men and women of different age group, Income group and job profiles. This study is restrained to the taxpayers located in Lucknow city of Uttar Pradesh. So, the conclusion derived from the research cannot be made applicable as it is for the other parts of the states or other states.
\end{abstract}

Keywords: Electronic Tax Filing; Taxpayers; E-Filing; Awareness; Perception.

Cite This Article: Dr. Mohammad Anees, and Mr. Mukesh Kumar. (2017). "PERCEPTION OF TAXPAYERS' TOWARDS E-FILE ADOPTION." International Journal of Research Granthaalayah, 5(11), 325-332. https://doi.org/10.29121/granthaalayah.v5.i11.2017.2359.

\section{Introduction}

In previous year's tax filing was a load full task for any individual as he/she has to go through a long process such as depositing the tax amount in the bank and then again queuing in for tax filing but by emerging technologies it has reduced to almost no effect. But with emerging technologies in new era one thing that is lacking is awareness and use of these technologies. Efiling is the process of filling your tax documents through internet with the help of software's or by registering yourself to the income tax website. In India, e-filing of income tax was introduced in September, 2004, initially on a voluntary usage basis for all categories of income tax Assessee. But from July, 2006, it was made mandatory for all corporate firms to e-file their 
income tax returns. Taking this process further, from assessment year 2007 to 2008, e-filing of income tax return was made mandatory for all companies and from 2013 Individuals having more than INR 10 lakh income are mandate for filling income tax online. Electronic filing options include:

1) Online, self-prepared return, using a personal computer and tax preparation software, or

2) Online submission of returns using a tax professional's computer and tax preparation software.

E-filing helped furnishing income tax returns through authorized intermediaries who were called e-return intermediaries. Response time for processing the income tax returns as well as claiming refund dropped significantly. An income tax return could be e-filed in three ways.

1) An Assessee could e-file his tax return on income tax website with digitally signature.

2) The return was filed on the income tax website, but without a digital signature.

3) To e-file their return through an e-return intermediary such as lawyers, CAs or TRPs who on payment of a prescribed fee, would did the e-filing and also assisted the Assessee in submitting the ITR-V to Income Tax Department.

\section{Literature Review}

E-tax filing is a new channel to pay taxes via electronic medium such as the Internet. Although it is convenient, easy, flexible and available 24/7, the innovation might cause some problems to consumers. Most of the literature related to tax e-filing adoption, applies and extends the wellknown Technology Acceptance Model (TAM) by Davis (1989) (Wang, 2002; Chang et al., 2005; Gallant et al., 2007), Theory of Planned Behavior (TPB) by Fishbein and Ajzen (1975), (Hsu and Chiu, 2004; Hung et al., 2006) and a unified model of both theories (Fu et al., 2006 ) to assess the adoption intention of the e-filing system.

Hite and McGill in their study state that tax practitioners must be a credible source of information for tax payers they are to offer tax advice and have it receipted. As tax system become more complex tax payers turn to tax practitioners for expert advice.

Kalyani, in her study on tax planning of salaried employees in Coimbatore city of the financial year 1998-1999 identified that older the age higher the tax liability. Private sector employees get higher income than the government employees. Tax payment decreases when tax saving investment increases tax saving along with the income and employees preferred to invest in life insurances corporation provident fund and national savings certificates.

Kennedy and Henry A., in their study state that, the Income Tax Act may appear as though it is difficult to comprehend but once a methodical approach is employed in reading and using it, understanding the income tax law becomes easier. The reader should find out who is liable to pay the tax, based upon which the tax will be levied, the tax rates to be applied to the tax base and how or when the tax is to be paid. These are the four requirements of a tax law which can be found in the divisions of each part of the act. When these are identified, understanding of the other structural elements will not be difficult. 
Brahmbhatt Mamta (2012) in the paper “Tax Payers' Perception towards E-File Adoption: An Empirical Investigation" suggest that with proper assistance from the tax-filing system and service centers, people can be made familiar to filing income taxes online.

Mukesh Kumar and Dr Mohd Anees (2014) in the study "E-Filing: Creating New Revolution in Taxation of India" has highlighted the benefits and challenges of E-Filing. They stated that Income tax department has to promote e-filing campaigning and enhance some job opportunities as TRPs in the society so that people become more aware about this new opportunity. Like other researcher opinion they also state that main challenge is risk of security. Their study shows that the e-filing is the new effective method of filing income tax return through online and make epayment tax.

\section{Research Objectives}

1) To study present e-filing system provided by the Income Tax department.

2) To study the requirement and scope of e-filing system.

3) To investigate whether the tax payers have problems in using the e-filing system.

4) To study the gap between the present system of e-filing system and its requirement.

5) To recommend the suggestions for the revamp the present e-filing system in India.

\section{Research Methodology}

For the purpose of the study the targeted population was service class persons belonging to Lucknow city of different ranks and classes of various organizations. 150 questionnaires were collected from various respondents out of which 84 were used to analyze the results by using mean score for ranking through SPSS and MS Excel. Here Rank 1 means most prominent problem or most convenient level for filing questionnaire and Rank 10 means least Sevier problem or least convenient level. Considering the objectives of study descriptive type research design is adopted to have more accuracy and rigorous analysis of research study.

\section{Data Analysis and Interpretation}

\begin{tabular}{|l|l|}
\multicolumn{2}{|c|}{ Severity of Problem (Table 1) } \\
\hline Problem Areas & Mean Ranking \\
\hline Lack of computer and internet availability & 5.81 \\
\hline Lack of experience and knowledge to e-file & 3.37 \\
\hline Unsuccessful attempt to e-file & 4.63 \\
\hline Do not have digital certificate or PIN to do & 7.04 \\
\hline Lack of trust on e-filing & 5.56 \\
\hline Problem of cost of e-filing & 5.90 \\
\hline No incentive for using e-filing & 5.38 \\
\hline Problem in online payments for ITR & 6.14 \\
\hline Problem of using computer software for e-filing & 4.82 \\
\hline Problem regarding e-intermediaries services & 6.51 \\
\hline
\end{tabular}




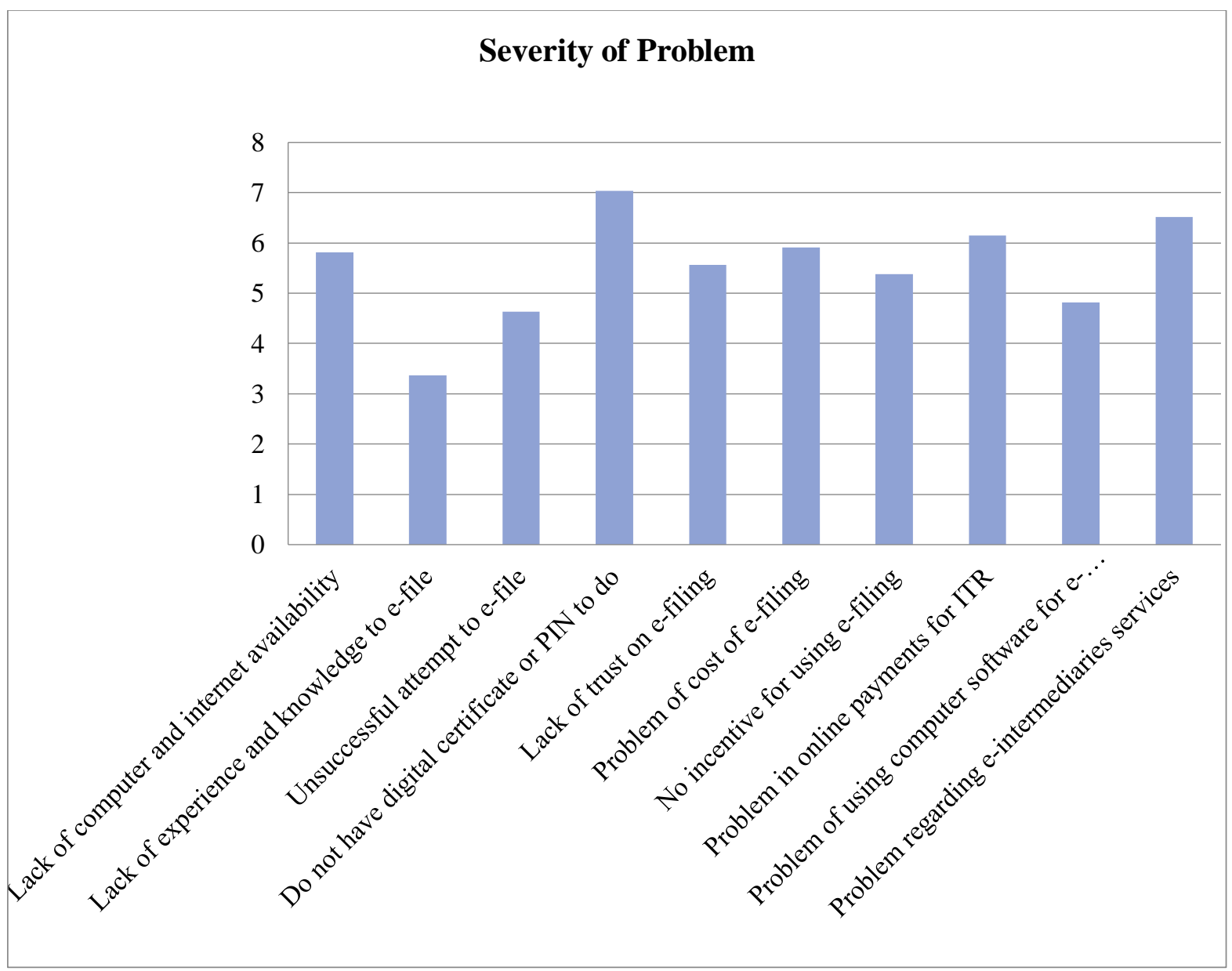

Figure 1:

The above table simply shows that from the given ten problems most of the assesse thinks that 'Lack of experience and knowledge to e-file' is the major problem for not filing income tax electronically, while Unsuccessful attempt to e-file, Problem of using computer software for efiling, Problem regarding e-intermediaries services' and 'online payment of tax' are also some major problems for not filing income tax electronically. Government has to provide proper guidelines and assistance to individuals for e-filing.

Convenience level of individual tax payers (Table2)

\begin{tabular}{|l|l|}
\hline Various aspects of e-filing & Mean Ranking \\
\hline Procedure of e- filing & 3.04 \\
\hline Accuracy of e-filing & 3.73 \\
\hline Easiness of e-filing & 3.17 \\
\hline Safety in e-filing & 5.50 \\
\hline Satisfied with e-filing fee & 5.45 \\
\hline Satisfied with the functioning of e-filing website & 6.02 \\
\hline Satisfaction with computer software for e-filing & 6.68 \\
\hline Satisfaction regarding e-payment facility provided by bank & 6.62 \\
\hline Satisfied with e-intermediaries services & 4.67 \\
\hline
\end{tabular}




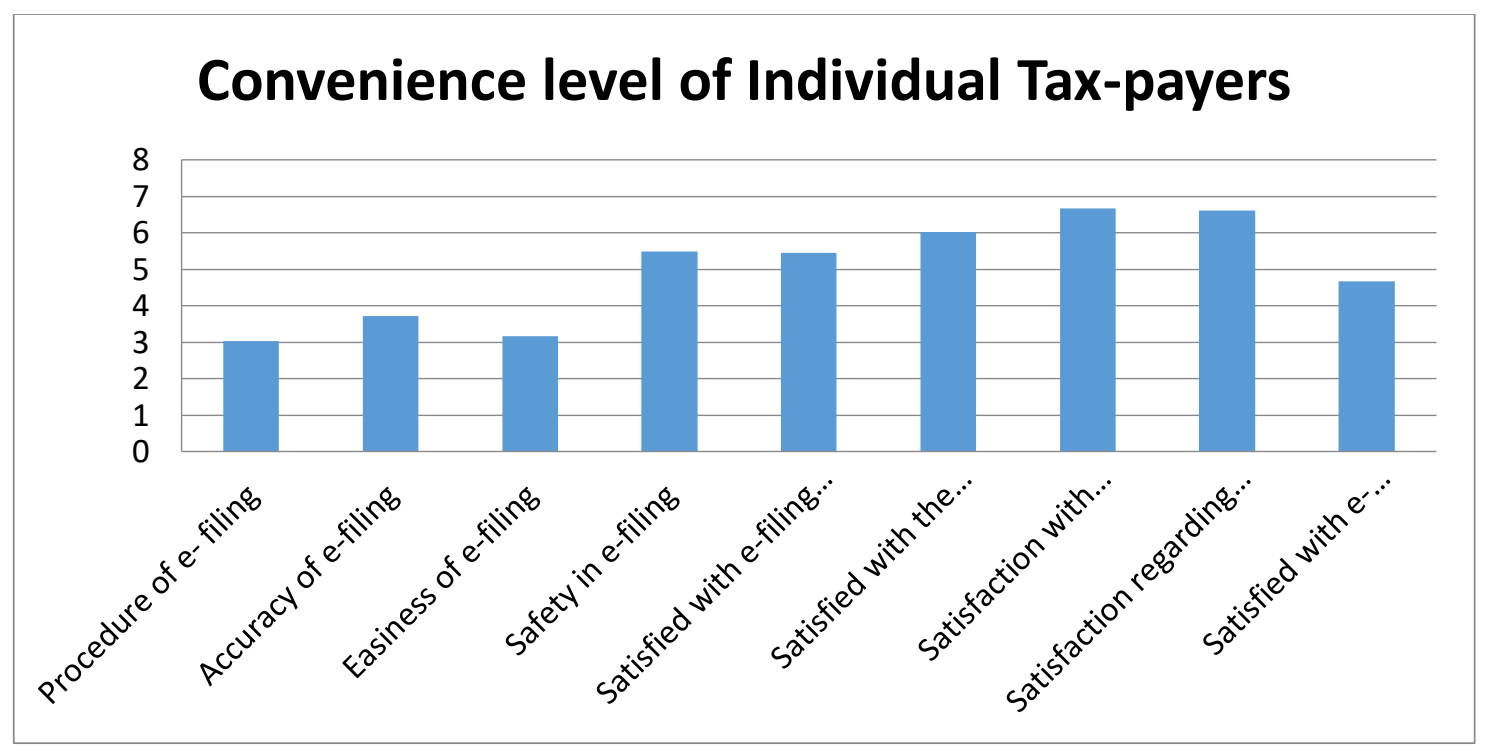

Figure2

The above table and figure 2 simply shows that because of simple procedure and easiness of filing system most of the individuals adopted the e-filing system and the level of accuracy which is attained through e-filing is attained is appreciable. On the other hand government should consider that individuals are not very comfortable in using computer software and e-payment of tax through net banking, so government should try to make it more easy and comfortable. The reasons for using e-file are summarized as follows.

Reasons for using e-file (Table3)

\begin{tabular}{|l|l|}
\hline Parameters & Mean Ranking \\
\hline For global requirement & 3.286 \\
\hline To control tax evasion & 3.048 \\
\hline To increase the tax revenue & 1.952 \\
\hline To speed up the tax refund & 2.381 \\
\hline To have the database available for research purpose & 5.762 \\
\hline To make a user friendly taxation system & 4.571 \\
\hline
\end{tabular}

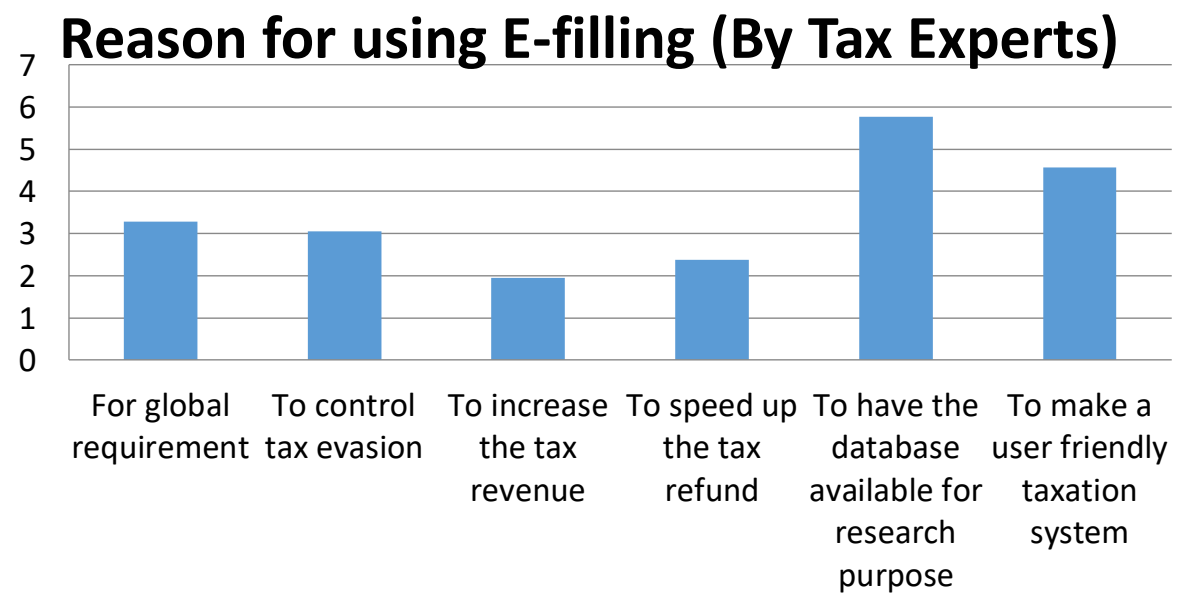

Figure3 
With regards to reason for using e-file this table becomes more important and useful because this table and charts only covers those aspects of e-filing which is filled by tax experts only. Most of the experts think that the main reason to introduce e-filing is to increase revenue and to speed up the refund procedure. While the data collected through e-filing is also used for research purpose also. The overall experience of individuals who file return electronically is summarized in the following table and chart.

\section{Overall experience of e-filers (Table4)}

\begin{tabular}{|l|l|}
\hline Parameters & $\begin{array}{l}\text { Average Score of } \\
\text { Parameters }\end{array}$ \\
\hline Good \& convenient & 22 \\
\hline Need Improvement & 62 \\
\hline Tedious and should be scraped & 0 \\
\hline
\end{tabular}

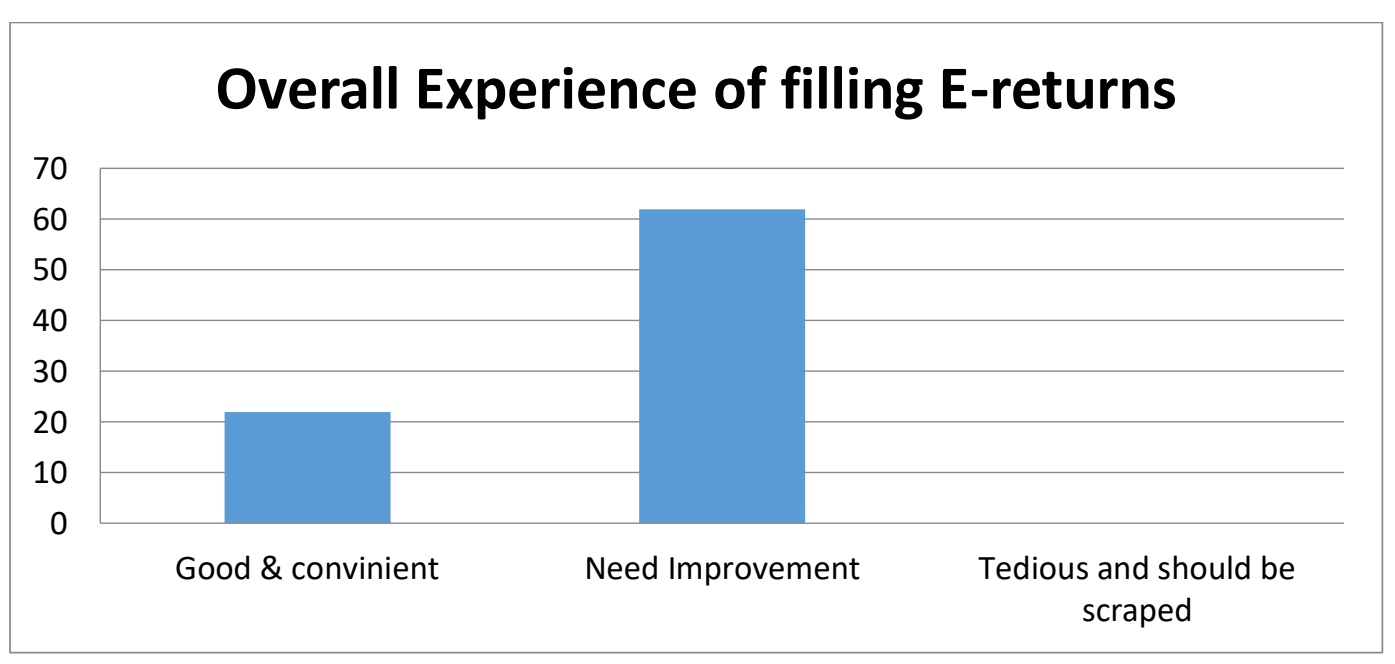

Figure4

Overall, it can be concluded that more than $74 \%$ of the e-filers agree to the fact that e-filing needs improvement. $26 \%$ of e-filers feel that e-filing is good and convenient. And a great thing hidden in this chart is that almost zero percent individual thinks that it is tedious and should be scraped.

\section{Major Findings}

This study simply reveals that more than $74 \%$ of the e-filers agree to the fact that e-filing needs improvement. $26 \%$ of e-filers feel that e-filing is good and convenient. From the survey we can accept that individuals have lack of computer and internet knowledge and they are also facing problem in using computer software for e-filing but as well as they feel comfortable with the procedure and easiness of e-filing. From the survey result it can also be said that most of the tax payers; have the positive perception on e-filing system. A majority of the tax payers have own enough facility to use e-Filing system at home as well as at their workplace. 


\section{Limitations}

1) The survey was conducted only in Lucknow city. Hence the results arrived at from this study may not be applicable to other areas.

2) This study mainly focuses on assessing awareness and satisfaction level of tax payers about e-filing of income tax returns.

\section{Conclusion}

This study reveals that some users are less satisfied with the e-filing facilities but most of the individual tax payers are not aware of the e-filing and e-payment procedures so sufficient steps are required to create more awareness in the minds of tax payers regarding e-filing of income tax. Taxpayers should be encouraged to use e-filing as there are many benefits of this system (both to government and to Taxpayers). The number of Tax return Preparer's (TRPs) should be increased in not only in luck now but in all over India, so that they serve the individual at ground level with expert view. Government has been extensive advertisement in national news papers; this can be extended to local news papers and using radio stations and local channels through local languages. The awareness can be best spread by introducing the e-filing collage curriculum and provide some certification courses.

Thus, the tax authorities should have to develop marketing strategies to reduce and resolve the efiling related issues. As Indian government take a bold step to introduce new technology to tax payers for filing their income tax returns through online is e-filing, so it's our responsibility to adopt it and spread it to others for saving everyone golden time, energy and cost and also reduces our tension.

\section{References}

[1] Lee, N. and Ian Lings, (2010) "Doing Business Research- A Guide to theory and Practice", Sage Publication.

[2] Fishbein, M. and Ajzen, I. (1975), Belief, Attitude, Intention and Behavior: An Introduction to Theory and Research, Addison-Wesley, Reading, MA.

[3] Davis, FD. (1989), 'Perceived Usefulness, Perceived Ease of Use, and User Acceptance of Information Technology,' MIS Quarterly, 13 (3), 319-340.

[4] Hite and McGill, (McGill, 1992)Tax spends, what causes what: International Journal of Business

[5] Kalyani, (1992) A study of tax planning of salaried employees in Coimbatore city.

[6] Kennedy Henry, A, (1992) Publisher: The Canadian Institute of Chartered Accountants Publication Name: CA Magazine, Subject: Business, ISSN: 0317-6878

[7] Yi-Shun Wang,(2002)The adoption of electronic tax filing systems: an empirical study, Government Information Quarterly 20 (2002) 333-352

[8] Yusniza Kamarulzaman and Anna A. Che Azmi, (2010) Tax e-filing adoption in Malaysia: A Conceptual Model, Journal of E-Government Studies and Best Practices Vol. 2010 (2010), Article ID 175966, 6 pages.

[9] Dr. Sujeet Kumar Sharma \& Dr. Rajan Yadav (2011) “An Empirical Study On Tax Payer's Attitude Towards E- Return Filing In India"

[10] Brahmbhatt Mamta (2012) "Tax Payers' Perception towards E-File Adoption: An Empirical Investigation" 
[11] Dr. Chanchal Chawla, Dr. Vipin Jain, Anand Joshi and Dr. Vinayak Gupta,(2013) A study of satisfaction level and awareness of tax payers towards e-filing of income tax return-with special reference to Moradabad city, International Monthly Refereed Journal of Research In Management \& Technology, ISSN-23200073, Volume II, November 2013

[12] Mukesh Kumar and Dr Mohd Anees (2014) "E-Filing: Creating New Revolution in Taxation of India".

[13] Geetha R. and Sekar M.Research, E-Filing of Income Tax: Awareness and Satisfaction level of individual Tax payers in Coimbatore city, India. Journal of Management Sciences.

*Corresponding author.

E-mail address: drmohdanees@ gmail.com, mkumar2k9@ gmail.com 